\title{
Molecular mimicry, inflammatory bowel disease, and the vaccine safety debate
}

\author{
Susy Yusung ${ }^{1 *}$ and Jonathan Braun ${ }^{2}$
}

\begin{abstract}
Preventive immunization has provided one of the major advances in population health during the past century. However, a surprising cultural phenomenon is the emergence of concerns about immunization safety, in part due to prominently controversial biomedical studies. One ongoing theoretical safety concern is the possibility of human molecular mimicry by measles, mumps, rubella (MMR) antigens. The study of Polymeros et al. in this BMC Medicine presents a systematic evaluation and refutation of this safety concern. This provides significant new scientific evidence in support of the safety of pediatric vaccines, which will inform the ongoing policy and cultural understanding of this important public health measure.
\end{abstract}

Please see related research article: http://www.biomedcentral.com/1741-7015/12/139/abstract.

Keywords: Crohn's Disease, Ulcerative Colitis, humoral immunity, epitope spreading

\section{Background}

Measles virus is a highly contagious organism that can cause multiple organ system complications and even death. Introduction of the measles, mumps, rubella (MMR) vaccine in the 1970s has saved innumerable lives and attenuated severe morbidities globally. Despite these remarkable gains, a claim emerged in the 1990s which associated MMR vaccine with colitis and autism spectrum disorders [1-4]. These association studies have been recognized as methodologically flawed and in some instances factually erroneous by the scientific and medical communities [5]. However, doubt and even outright rejection of the vaccine's safety still linger in various niches of our society. These concerns have also reverberated in the inflammatory bowel disease (IBD) community, in part related to the publication of a study series implying measles infection or vaccination with the live attenuated virus mediate pathogenesis of Crohn's disease (CD) $[3,4,6]$. Despite recognition that these studies were flawed in methodology and hypothesis, they continue to provoke much debate and inquiry into the role of measles virus in the pathogenesis of IBD.

\footnotetext{
* Correspondence: syusung@labiomed.org

'Department of Pediatrics, Harbor-UCLA Medical Center, 1000 W Carson St, Torrance, CA 90502, USA

Full list of author information is available at the end of the article
}

\section{Biologic context}

Exposure to environmental antigens has long been suspected to induce development of IBD in genetically susceptible individuals. The ease of transmission and pervasiveness of certain infectious organisms makes the possibility of micro-organisms as antigenic triggers of IBD into a tantalizing hypothesis. The discovery that certain bacterial communities instigate inflammation of the gut mucosa further intensified research of the microbiome and simultaneously heightened awareness of elegant mechanisms by which viruses may serve as potential regulators of gut mucosal inflammation [7]. In this context, a number of viruses have been studied in association with human $\mathrm{CD}$ - measles virus being one of the most commonly studied, preceded by cytomegalovirus and Epstein-Barr virus [8].

Several groups have investigated the plausible link between measles and IBD either through epidemiological studies or biological analysis of tissue specimens. A study published in 1995 first suggested that recipients of measles vaccination had a three-fold increased risk of developing $\mathrm{CD}$ and ulcerative colitis (UC) compared to unvaccinated controls; however, this study was found to be limited by methodological flaws and could not be validated $[6,9]$. Carefully designed studies thereafter demonstrated no increased risk of $C D$ in children vaccinated with MMR $[10,11]$. Studies also comparing the frequency of measles seropositivity in CD, UC and healthy populations found 
no significant differences between all three groups $[12,13]$. In addition to these epidemiological studies, efforts have been made to detect the presence of persistent measles virus in tissue or serum samples from IBD patients using PCR and immunohistochemical techniques. Results of those immunohistochemical studies have been discordant and contradictory $[2,14]$, while the highly sensitive reverse PCR method failed to detect any measles virus genome in the intestinal tissues of $C D$ patients [15-17]. In light of these studies, several investigators have proposed a 'measles related antigen' in the human intestine which shares identical epitopes with the measles virus and induces immune reactivity through mechanisms of molecular mimicry [18-20].

In a study published in BMC Medicine, Polymeros et al. [21] revisit the issue of measles-induced molecular mimicry as a mechanism which directs immune dysregulation in CD. Firstly, this study is distinguishable from prior studies by virtue of combined employment of experimental immunologic data, bioinformatics, and detailed molecular analysis of measles virus and human antigens. Results from prior immunological studies have demonstrated the development of antibodies against HEMA and VGLF antigens following vaccination, isolating these viral proteins as candidates for intestinal antigen mimicry. The antigenic potential of HEMA and VGLF epitopes are verified using prediction algorithms and, subsequently, human intestinal proteins which share these antigenic epitopes are identified and analyzed as potential viral mimic candidates. Thus, the utilization of technically validated methods and algorithms serve as platforms for identification of candidate mimic proteins.

The paper identifies several candidate intestinal peptides as potential measles virus antigen mimics. Changes in the expression of some of the peptides, such as intestinal fatty acid binding protein and sucrase isomaltase, have been previously associated with intestinal inflammation in $C D$ patients. Another protein TOG, had been previously identified as sharing sequence analogue with Mycobacterium avium paratuberculosis (MAP), and antibodies reactive to this protein were found in both CD and healthy controls [22]. Although these intestinal proteins appear to be viable measles mimic candidates, no significant differences in reactivity to any of these antigens were found among $C D$, UC and healthy controls. Moreover, there were no significant differences in reactivity to highly antigenic epitopes of HEMA or VGLF among CD, UC and healthy individuals. These results are in contrast to previous studies by the present investigators, which found cross-reactivity between two sets of MAP and human intestinal peptides although the observed cross reactivity was well within the random rates predicted for heterologous peptides. In comparison, the lack of any cross reactivity between measles and human intestinal peptides reinforces the high unlikelihood of the measles virus having a role in CD pathogenicity via the mechanism of molecular mimicry.

\section{Conclusions}

At a biologic level, the present study of Polymeros et al. thus is a fresh test of the hypothesis of microbial molecular mimicry in the pathogenesis of IBD, and provides thoughtful and fastidious evidence against this hypothesis. As we have noted, molecular mimicry is the putative link of concern between MMR vaccine and IBD risk. Accordingly, at the level of public safety and policy, this paper provides important new evidence against this link. This carefully performed study should be an important new reassurance to concerned families and medical caregivers on the safety of the MMR vaccine with respect to IBD susceptibility.

\section{Competing interests}

The authors declare that they have no competing interests.

\section{Authors' contributions}

SY and JB equally contributed to the conception, literature review, and composition of this paper. Both authors read and approved the final manuscript.

\section{Acknowledgements}

The study was supported by NIH DK46763 (JB), UCLA Clinical and Translational Science Institute (UL1 TR000124), and NIH T32 DK07180-37(SY).

\section{Author details}

${ }^{1}$ Department of Pediatrics, Harbor-UCLA Medical Center, 1000 W Carson St, Torrance, CA 90502, USA. '2Department of Pathology and Laboratory Medicine, UCLA, 10833 Le Conte Ave, Los Angeles, CA 90095, USA.

Received: 29 August 2014 Accepted: 29 August 2014

Published online: 18 September 2014

\section{References}

1. Wakefield AJ, Ekbom A, Dhillon AP, Pittilo RM, Pounder RE: Crohn's disease: Pathogenesis and persistent measles virus infection. Gasteroenterology 1995, 108:911-916

2. Balzola FA, Kahn K, Pera A, Bonino F, Pounder RE, Wakefield AJ: Measles IgM immunoreactivity in patients with inflammatory bowel disease. Ital J Gastroenterol Hepatol 1998, 30:378-382.

3. Lewin J, Dhillon AP, Sim R, Mazure G, Pounder RE, Wakefield AJ: Persistent measles virus infection of the intestine: confirmation by immunogold electron microscopy. Gut 1995, 36:564-569.

4. Wakefield AJ, Murch SH, Anthony A, Malik JLDMCM, Berelowitz M, Dhillon AP, Thomson MA, Harvey P, Valentine A, Davies SE, Walker-Smith JA: lleal-lymphoid-nodular hyperplasia, non-specific colitis, and pervasive developmental disorder in children. Lancet 1998, 351:637-641. Retraction in: Lancet 2010, 375:445.

5. Flaherty DK: The vaccine-autism connection: a public health crisis caused by unethical medical practices and fraudulent science. Ann Pharmacother 2011, 45:1302-1304.

6. Thompson NP, Montgomery SM, Pounder RE, Wakefield AJ: Is measles vaccination a risk factor for inflammatory bowel disease? Lancet 1995, 345:1071-1074.

7. Cadwell K, Patel KK, Maloney NS, Liu TC, Ng AC, Storer CE, Head RD, Xavier R, Stappenbeck TS, Virgin HW: Virus-plus-susceptibility gene interaction determines Crohn's disease gene Atg16L1 phenotypes in intestine. Cell 2010, 141:1135-1142

8. Wagner J, Sim WH, Lee K, Kirkwood CD: Current knowledge and systematic review of viruses associated with Crohn's disease. Rev Med Virol 2013, 23:145-171. 
9. Morris DL, Montgomery SM, Thompson NP, Ebrahim S, Pounder RE, Wakefield AJ: Measles vaccination and inflammatory bowel disease: a national British Cohort Study. Am J Gastroenterol 2000, 95:3507-3512.

10. Davis RL, Kramarz P, Bohlke K, Benson P, Thompson RS, Mullooly J, Black S, Shinefield H, Lewis E, Ward J, Marcy SM, Eriksen E, Destefano F, Chen R, Vaccine Safety Datalink Team: Measles-mumps-rubella and other measles-containing vaccines do not increase the risk for inflammatory bowel disease: a case-control study from the Vaccine Safety Datalink project. Arch Pediatr Adolesc Med 2001, 155:354-359.

11. Seagroatt V: MMR vaccine and Crohn's disease: ecological study of hospital admissions in England, 1991 to 2002. BMJ 2005, 330:1120-1121.

12. Feeney M, Clegg A, Winwood P, Snook J: A case-control study of measles vaccination and inflammatory bowel disease. Lancet 1997, 350:764-769.

13. Bernstein CN, Rawsthorne P, Blanchard JF: Population-based case-control study of measles, mumps, and rubella and inflammatory bowel disease. Inflamm Bowel Dis 2007, 13:759-762.

14. lizuka M, Chiba M, Yukawa M, Nakagomi T, Fukushima T, Watanabe $\mathrm{S}$, Nakagomi O: Immunohistochemical analysis of the distribution of measles related antigen in the intestinal mucosa in inflammatory bowel disease. Gut 2000, 46:163-169.

15. Haga Y, Funakoshi O, Kuroe K, Kanazawa K, Nakajima H, Saito H, Murata Y, Munakata A, Yoshida Y: Absence of measles viral genomic sequence in intestinal tissues from Crohn's disease by nested polymerase chain reaction. Gut 1996, 38:211-215.

16. Chadwick N, Bruce IJ, Schepelmann S, Pounder RE, Wakefield AJ: Measles virus RNA is not detected in inflammatory bowel disease using hybrid capture and reverse transcription followed by the polymerase chain reaction. J Med Virol 1998, 55:305-311.

17. Afzal MA, Armitage E, Begley J, Bentley ML, Minor PD, Ghosh S, Ferguson A: Absence of detectable measles virus genome sequence in inflammatory bowel disease tissue and peripheral blood lymphocytes. J Med Virol 1998, 55:243-249.

18. Ohteki T, Hessel A, Bachmann MF, Zakarian A, Sebzda E, Tsao MS, McKall-Faienza K, Odermatt B, Ohashi PS: Identification of a cross-reactive self ligand in virus-mediated autoimmunity. Eur J Immunol 1999, 29:2886-2896.

19. Benoist C, Mathis D: The pathogen connection. Nature 1998, 394:227-228.

20. Narayanan S: Molecular mimicry: basis for autoimmunity. Indian I Clin Biochem 2000, 15:78-82.

21. Polymeros D, Tsiamoulos ZP, Koutsoumpas AL, Smyk DS, Mytilinaiou MG, Triantafyllou K, Bogdanos DP, Ladas SP: Bioinformatic and immunological analysis reveals lack of support for measles virus related mimicry in Crohn's disease. BMC Med 2014, 12:139.

22. Polymeros D, Bogdanos DP, Day R, Arioli D, Vergani D, Forbes A: Does cross-reactivity between Mycobacterium avium paratuberculosis and human intestinal antigens characterize Crohn's disease? Gastroenterology 2006, 131:85-96.

doi:10.1186/s12916-014-0166-6

Cite this article as: Yusung and Braun: Molecular mimicry, inflammatory bowel disease, and the vaccine safety debate. BMC Medicine 2014 12:166.

\section{Submit your next manuscript to BioMed Central and take full advantage of:}

- Convenient online submission

- Thorough peer review

- No space constraints or color figure charges

- Immediate publication on acceptance

- Inclusion in PubMed, CAS, Scopus and Google Scholar

- Research which is freely available for redistribution 